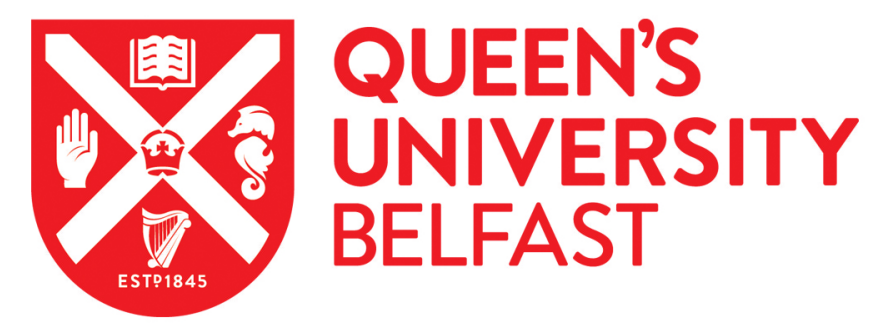

\title{
Multi-mycotoxin determination in rice, maize and peanut products most consumed in Côte d'Ivoire by UHPLC-MS/MS
}

Manizan, A. L., Oplatowska-Stachowiak, M., Piro-Metayer, I., Campbell, K., Koffi-Nevry, R., Elliott, C., Akaki, D., Montet, D., \& Brabet, C. (2018). Multi-mycotoxin determination in rice, maize and peanut products most consumed in Côte d'Ivoire by UHPLC-MS/MS. Food Control, 87, 22-30.

https://doi.org/10.1016/j.foodcont.2017.11.032, https://doi.org/10.1016/j.foodcont.2017.11.032

Published in:

Food Control

Document Version:

Peer reviewed version

Queen's University Belfast - Research Portal:

Link to publication record in Queen's University Belfast Research Portal

Publisher rights

(c) 2017 Elsevier Ltd.

This manuscript is distributed under a Creative Commons Attribution-NonCommercial-NoDerivs License

(https://creativecommons.org/licenses/by-nc-nd/4.0/), which permits distribution and reproduction for non-commercial purposes, provided the author and source are cited.

\section{General rights}

Copyright for the publications made accessible via the Queen's University Belfast Research Portal is retained by the author(s) and / or other copyright owners and it is a condition of accessing these publications that users recognise and abide by the legal requirements associated with these rights.

Take down policy

The Research Portal is Queen's institutional repository that provides access to Queen's research output. Every effort has been made to ensure that content in the Research Portal does not infringe any person's rights, or applicable UK laws. If you discover content in the Research Portal that you believe breaches copyright or violates any law, please contact openaccess@qub.ac.uk. 


\title{
Multi-mycotoxin determination in rice, maize and peanut products most consumed in Côte d'Ivoire by UHPLC-MS/MS
}

Ama Léthicia Manizan ${ }^{\mathrm{a}}$, Michalina Oplatowska-Stachowiak ${ }^{\mathrm{b},}$ Isabelle Piro-Metayer ${ }^{\mathrm{c}}$, Katrina Campbell $^{\mathrm{b}}$, Rose Koffi-Nevry ${ }^{\mathrm{a}}$, Christopher Elliott ${ }^{\mathrm{b}}$, David Akaki ${ }^{\mathrm{d}}$, Didier Montet ${ }^{\mathrm{c}}$, Catherine Brabet $^{\mathrm{c}}$

${ }^{a}$ UNA, UFR des Sciences et Technologie des Aliments, Laboratoire de Biotechnologie et Microbiologie des Aliments, 02 BP 801 Abidjan, Côte d'Ivoire manizanlethicia@ yahoo.fr rosenevry2@gmail.com

${ }^{\mathrm{b}}$ Institute for Global Food Security, School of Biological Sciences, Queen's University, David Keir Building, Stranmillis Road, Belfast, UK BT9 5HN michalina.oplatowska@europroxima.com katrina.campbell@qub.ac.uk chris.elliott@qub.ac.uk

${ }^{\mathrm{c}}$ CIRAD, UMR Qualisud, 73 rue Jean-François Breton, 34398 Montpellier Cedex 5, France isabelle.piro-metayer@cirad.fr didier.montet@ cirad.fr

${ }^{\mathrm{d}}$ INP-HB, Département Génie Chimique et Agro-alimentaire, Laboratoire des Procédés Industriels de Synthèse, de l'Environnement et des Énergies Nouvelles, BP 1313 Yamoussoukro, Côte d'Ivoire davidakaki@yahoo.fr

Corresponding author: Catherine Brabet, catherine.brabet@ cirad.fr

\begin{abstract}
The aim of this study was to determine the multi-mycotoxin occurrence in cereal and oilseed products most consumed in Côte d'Ivoire. A total of 238 samples of rice ( 88 produced locally or imported), maize (79, cracked or flour) and peanut paste (71) were collected in the main markets of Abidjan, Bouaké and Korhogo. An UHPLC-MS/MS method allowed the analysis of 77 mycotoxins. All the peanut paste samples were contaminated by aflatoxin $B_{1}$ (AFB1) with $99 \%$ exceeding the EU limits of $2 \mu \mathrm{g} \cdot \mathrm{kg}^{-1}$ for AFB1 and $4 \mu \mathrm{g} \cdot \mathrm{kg}^{-1}$ for total aflatoxins (AFT: B1+B2+G1+G2), and concentrations reaching up to $4535 \mu \mathrm{g} \cdot \mathrm{kg}^{-1}$ (AFB1) and $8094 \mu \mathrm{g} \cdot \mathrm{kg}^{-1}$ (AFT). Maize (96\%) and rice (57\%) samples were also contaminated by AFB1 with $58 \%$ and $24 \%$ respectively above the EU limits and maximum levels of $80 \mu \mathrm{g} \cdot \mathrm{kg}^{-1}$ for maize and $14 \mu \mathrm{g} \cdot \mathrm{kg}^{-1}$ for rice. Only $6 \%$ of the cereal samples ( 3 rice and one maize samples) had ochratoxin A content above the EU limit ( $\left.3 \mu \mathrm{g} \cdot \mathrm{kg}^{-1}\right)$. Fumonisins and zearalenone were detected, respectively, in $91 \%$ and $8 \%$ of the maize samples, and in $18 \%$ and $5 \%$ of the rice samples but at levels below EU limits. Out of the 238 samples, $91 \%$ were contaminated with more than one mycotoxin including EU regulated mycotoxins and/or other
\end{abstract}


mycotoxins mainly beauvericin (79\% of the samples), equisetin (71\%), aflatoxin M1 (45\%), cyclopiazonic acid (32\%), fumonisin B3 (29\%), sterigmatocystin (24\%), citrinin (18\%), ochratoxin B (16\%) and fusaric acid (15\%). The peanut paste samples represented the highest risk to consumer health followed by maize and rice samples.

Keywords: Mycotoxins, Cereals, Rice, Maize, Peanut, Côte d'Ivoire

\section{Introduction}

Mycotoxins are secondary metabolites of filamentous fungi that colonize a wide range of crops, including cereals and oilseeds, both in the field and after harvest, especially during storage. Due to their thermal and chemical stability, mycotoxins can also be found in processed foods of plant origin, or by transfer, in food products of animal origin such as milk, eggs, meat and offal from animals consuming contaminated feed. These natural contaminants represent a major concern for human and animal health since they can cause acute or chronic intoxications which are sometimes fatal due to their various toxic effects (carcinogenic, hepatotoxic, nephrotoxic, neurotoxic, genotoxic, immunotoxic, oestrogenic...). More than 300 mycotoxins have been identified, but attention is given mainly to those with greatest public health and agro-economic significance. The most common genera of mycotoxigenic fungi in food and feed are Aspergillus, Fusarium, Penicillium, Claviceps and Alternaria (AFSSA, 2006; Zain, 2011). In order to protect consumer health, many countries worldwide, and in particular Europe, have established regulatory limits and guidance values for certain mycotoxins in foodstuffs (European Commission, 2006, 2013; Van Egmond, Schothorst, \& Jonker, 2007). Recently, there is a growing interest in the occurrence and toxicity of emerging Fusarium mycotoxins (beauvericin, fusaproliferin, moniliformin, and enniatins A, A1, B, B1) and biologically modified forms of certain mycotoxins (EFSA, 2014a, 2014b; Jestoi, 2008). The latter include Fusarium mycotoxins conjugated to polar compounds by plants (the so called masked mycotoxins) or fungi (EFSA, 2014a; Rychlik et al., 2014). The co-occurrence of different mycotoxins within the same food almost always occurs and may result in a greater toxicity to humans due to possible additive or synergistic effects (Alassane-Kpembi et al., 2017; Grenier \& Oswald, 2011). A consumer survey conducted under the 3CIvoire project (EuropeAid/129596/L/ACT/CI DCI-NSAPVD/2010/64) has revealed that rice, maize and peanut are among the most consumed cereals and oilseeds in Côte d'Ivoire. In this country, rice consumption has been reported to account for more than half of the cereal intake (Boansi, 2013). As its production satisfies only about $50 \%$ of the domestic consumption, it is massively imported mainly from Asian countries (USDA, 2015). Maize is consumed in various forms, in particular as "Kabatoh" which is a cooked dough prepared from maize flour with or without potash (Yeo, 2011). 
Like rice and maize, peanut is considered a staple food crop because of its use not only as an important oil crop, but also for the paste produced from ground roasted seeds (Sangare, Koffi, Akamou, \& Fall, 2009). So far, data on multiple mycotoxins in rice, maize, peanut and derived products (maize flour and peanut paste) are limited in Côte d'Ivoire and whereby the attention has been mainly concerned with those under EU regulation. The aim of the present study was to investigate the occurrence of 77 mycotoxins in the cereal (rice grains, cracked maize and maize flour) and oilseed (peanut paste) products that are most consumed by the Ivorian population in order to contribute to food safety risk assessment in Côte d'Ivoire.

\section{Materials and methods}

\subsection{Food samples}

In April 2013, 238 food samples (between 260 and $560 \mathrm{~g}$ each) intended for direct human consumption or use as an ingredient in foodstuffs were collected in the main markets of Abidjan, Bouaké and Korhogo, Côte d'Ivoire: 88 rice samples (47 produced locally and 41 imported), 79 maize samples (29 cracked maize, 32 and 18 flour samples respectively with potash and without potash) and 71 peanut paste samples. They were sampled in new plastic bags following the sales practices and immediately kept at $4{ }^{\circ} \mathrm{C}$, then stored at $-20^{\circ} \mathrm{C}$ until sample preparation.

\subsection{Sample preparation and storage}

Frozen rice and cracked maize samples were finely ground with a Retsch mill (ZM 200, sieve 1$\mathrm{mm})$. The ground samples and the maize flour samples previously thawed were homogenized for 30 min using a Chopin MR2L mixer. Peanut paste samples were thawed and homogenized for 15 min with a blender (Thermomix VORWERK TM 21) by selecting the speed 2.5. Homogenized samples were kept at $-20^{\circ} \mathrm{C}$ until mycotoxin analysis.

\subsection{Multi-mycotoxin analysis}

The QuEChERS extraction procedure and UHPLC-MS/MS method described in detail by Oplatowska-Stachowiak et al. (2015) was used to determine and quantify (or semi-quantify) 77 mycotoxins (Table 1) in the 238 homogenized maize and rice flour and peanut paste samples. Standards obtained in powder form were prepared at the concentration $1 \mathrm{mg} / \mathrm{mL}$ in the appropriate amount of solvent (MeCN or $\mathrm{MeOH}$ ) according to the manufacturer's instructions. Three different solutions of standards were prepared as calibrants for the instrument to determine the limits of detection (LOD) and quantification (LOQ) (Table 1) for each mycotoxin analysed. Standard set 1 contained a concentrated stock solution of all the mycotoxins included in the method except for 
fumonisins B1 (FB1), B2 (FB2) and B3 (FB3); the four masked zearalenone metabolites; zearalenone14-sulfate (ZEN-14-Sulf); deoxynivalenol-3-glucoside (DON-3-Glc); and moniliformin (MON). Standard set 2 contained FB1, FB2, and FB3. Standard set 3 contained the four masked zearalenone metabolites, ZEN-14-Sulf, DON-3-Glc, and MON. The mycotoxins were assigned to seven different calibration groups as described by Oplatowska-Stachowiak et al. (2015) depending on the requirements and/or sensitivity. These concentrated standard sets were also used for preparing calibrants in matrix. The mycotoxin quantitation was achieved by preparing matrix-matched calibration curves with blank maize or rice flour and peanut paste samples spiked before extraction to correct for the recovery losses. If the measured mycotoxin content in a sample was higher than the highest calibration point, the extracted sample was diluted and analysed again. The data was analyzed using TargetLynx processing software (Waters, Wilmslow, UK) whereby linear 1/x weighted calibration curves were calculated.

\section{Results and discussion}

\subsection{Multi-mycotoxin occurrence}

Out of the 238 food samples collected in Côte d'Ivoire, $91 \%$ were contaminated with more than one mycotoxin (about $21 \%$ between 2 and 4 mycotoxins, $21 \%$ between 5 and 7 and $48 \%$ with more than 8 ), $4 \%$ with only one mycotoxin (9 rice samples) and 5\% (12 rice samples) were not contaminated. The largest number of mycotoxins detected in the same sample was found in maize samples (14 in 3 samples) followed by peanut paste (13 in 6 samples) and rice samples ( 8 in 2 samples). However, the peanut paste samples were the most contaminated with multiple mycotoxins followed by the maize then rice samples, with at least 5 mycotoxins detected in the same sample (against 2 in both maize and rice samples). Furthermore, $94 \%$ of the peanut samples contained more than 8 mycotoxins (against 58\% and 2\% for maize and rice samples, respectively) (Table 2). Among the maize and rice samples, the maize flour samples without potash and the local rice samples were the most contaminated with multiple mycotoxins. A total of 24 mycotoxins (8 EU regulated and 16 others) were detected in all types of food samples, with 18, 17 and 15 from the rice, maize and peanut paste samples, respectively (Figure 1, Tables 3-6). Similar studies have also highlighted the co-existence of EU regulated and/or other mycotoxins in maize from Burkina Faso and Mozambique (Warth et al., 2012), Democratic Republic of Congo (DRC) (Mulunda, Dzoma, Nyirenda, \& Bakunzi, 2013), Nigeria (Ogara et al., 2016), South Africa (Chilaka et al., 2012; Shephard et al., 2013) and Tanzania (Kamala et al., 2015) and maize flour from Cameroon (Abia et al., 2013); rice from Nigeria (Makun, Dutton, Njobeh, Mwanza \& Kabiru, 2011; Makun, Gbodi, Akanya, Salako, \& 
Ogbadu, 2007); peanut from DRC (Mulunda et al., 2013) and peanut paste from Cameroon (Abia et al., 2013).

\subsection{EU regulated mycotoxins}

To date, there is no regulation for mycotoxins in foodstuffs in Côte d'Ivoire. Therefore, the EU maximum levels for mycotoxins in cereals (maize and rice), peanuts and derived products intended for direct human consumption (European Commission, 2006, 2007, 2010, 2012) are used for reference in the present article.

Aflatoxin B1 (AFB1) which is the predominant form of aflatoxins (AFs) in foods (AFSSA, 2006) was the most frequently detected EU regulated mycotoxin in the analysed food samples. Aflatoxins B2 (AFB2), G1 (AFG1) and G2 (AFG2) were also found in these samples but at a lower frequency and concentration than AFB1. AFs have been classified as Group 1 human carcinogens (IARC, 2002) with AFB1 being the most toxic followed by AFG1 then AFB2 and AFG2 (EFSA, 2007). The liver is the primary target organ. Acute high level aflatoxin exposure has resulted in deaths in some parts of the world, particularly in African countries, and chronic low-level aflatoxin exposure can increase the risk for human hepatocellular carcinoma and result in immune suppression (IARC, 2015; Zain, 2011). The peanut paste samples were the most contaminated with AFB1 and total aflatoxins (AFT: B1+B2+G1+G2) followed by the maize and rice samples (Table 3). This can be explained by the high peanut susceptibility to aflatoxin-producing fungi. AFB1 was recovered in $100 \%, 96 \%$ and $57 \%$ of the peanut paste, maize and rice samples, respectively; AFB2 in 99\%, 67\% and $30 \%$; AFG1 in 100\%, 57\% and 22\%; and AFG2 in 87\%, 24\% and 1\%. Contamination levels higher than the EU limit for AFB1 $\left(2 \mu \mathrm{g} . \mathrm{kg}^{-1}\right)$ were found in $99 \%, 61 \%$ and $42 \%$ of the contaminated peanut paste, maize and rice samples, respectively, and for AFT $\left(4 \mu \mathrm{g} \cdot \mathrm{kg}^{-1}\right)$ in $99 \%$, $53 \%$ and $32 \%$ of these respective samples. The highest levels and means were obtained in peanut paste samples for AFB1, AFG1 and AFT (Table 3), and for AFB2 (1098 $\mu \mathrm{g} . \mathrm{kg}^{-1}$, mean $\left.113 \mu \mathrm{g} \cdot \mathrm{kg}^{-1}\right)$ and AFG2 $\left(267 \mu \mathrm{g} \cdot \mathrm{kg}^{-1}\right.$, mean $\left.18 \mu \mathrm{g} \cdot \mathrm{kg}^{-1}\right)$. The rice samples had the lowest maximum levels and means for AFB1, AFG1 and AFT (Table 3) and for AFB2 $\left(1.1 \mu \mathrm{g} \cdot \mathrm{kg}^{-1}\right.$, mean $\left.0.6 \mu \mathrm{g} \cdot \mathrm{kg}^{-1}\right)$ and AFG2 $\left(0.9 \mu \mathrm{g} . \mathrm{kg}^{-1}\right.$ in one local rice sample). The highest levels quantified in maize samples were $80 \mu \mathrm{g} \mathrm{kg}^{-}$ ${ }^{1}$ for AFB1 (mean $8.6 \mu \mathrm{g} \cdot \mathrm{kg}^{-1}$ ), $84 \mu \mathrm{g} \cdot \mathrm{kg}^{-1}$ for AFG1 (mean $5.3 \mu \mathrm{g} \cdot \mathrm{kg}^{-1}$ ), $7 \mu \mathrm{g} \cdot \mathrm{kg}^{-1}$ for AFB2 (mean $1.5 \mu \mathrm{g} . \mathrm{kg}^{-1}$ ), $3.8 \mu \mathrm{g} . \mathrm{kg}^{-1}$ for AFG2 (mean $0.8 \mu \mathrm{g} \cdot \mathrm{kg}^{-1}$ ) and $173 \mu \mathrm{g} \cdot \mathrm{kg}^{-1}$ for AFT (mean $13 \mu \mathrm{g} \cdot \mathrm{kg}^{-1}$ ). Higher AFB1 contamination frequency and levels were also found in peanut paste or seed samples than in maize flour or grain samples from Cameroon and DRC (Abia et al., 2013 ; Mulunda et al., 2013), but Warth et al. (2012) in Burkina Faso and Mozambique found contrary results for the same types of samples. The high proportion of the food samples analysed in the present study with AFB1 levels exceeding the EU limit suggested that Ivoirians are at risk of chronic aflatoxin exposure. 
Concentrations up to around 2000 (in peanut paste), 40 (in maize) and 7 (in rice) fold more than the EU AFB1 and AFT limits can also induce severe acute forms of aflatoxicosis. Previous studies have also reported very high aflatoxin levels in peanut, maize and rice samples from African countries. AFT and AFB1 concentrations up to $11900 \mu \mathrm{g} \cdot \mathrm{kg}^{-1}$ and $937 \mu \mathrm{g} \cdot \mathrm{kg}^{-1}$, respectively, were found in peanut samples (Chala, Mohammed, Ayalew, \& Skinnes, 2013; Kamika \& Takoy, 2011; Mutegi, Ngugi, Hendriks, \& Jones, 2009). AFB1 levels up to $1081 \mu \mathrm{g} \cdot \mathrm{kg}^{-1}$ were reported in maize samples (Kamala et al., 2015) and up to $1642 \mu \mathrm{g} . \mathrm{kg}^{-1}$ in mouldy rice samples (Makun et al., 2007). In Côte d'Ivoire, Sangare-Tigori, Moukha, et al. (2006) detected AFB1 in 100\% of maize, rice and peanut samples from markets in Abidjan but with lower levels (up to $20 \mu \mathrm{g} \cdot \mathrm{kg}^{-1}$ ) than those quantified in the present study. Contrariwise, higher average levels of AFB1 $\left(108 \mu \mathrm{g} \cdot \mathrm{kg}^{-1}\right)$ and AFT $\left(129 \mu \mathrm{g} \cdot \mathrm{kg}^{-1}\right)$ with ranges of 5.7-309 $\mu \mathrm{g} . \mathrm{kg}^{-1}$ and 4.5-330 $\mu \mathrm{g} \cdot \mathrm{kg}^{-1}$, respectively, were found in maize flour samples from markets in Abidjan, with $100 \%$ of the samples contaminated (Kouadio, Lattanzio, Ouattara, Kouakou, \& Visconti, 2014). These latter researchers also detected AFB2, AFG1 and AFG2 at lower frequency and concentration than those of AFB1 but at higher average levels $\left(8 \mu \mathrm{g} \cdot \mathrm{kg}^{-1}\right.$ for both AFB2 and AFG1 and $6 \mu \mathrm{g} \cdot \mathrm{kg}^{-1}$ for AFG2) than those of the maize flour samples analysed in the present study.

Ochratoxin A (OTA) was detected in $65 \%, 22 \%$ and $15 \%$ of the peanut paste, maize and rice samples respectively, with only one maize sample and 3 rice samples exceeding the EU limit of 3 $\mu \mathrm{g} . \mathrm{kg}^{-1}$. For the cereal samples, the highest OTA level and mean were found in the rice samples (Table 4). OTA has been classified as a group 2B possible human carcinogen (IARC, 1993) and was associated with the Balkan Endemic Nephropathy (BEN). It is also thought to be teratogenic, hepatotoxic, neurotoxic and immunotoxic (Köszegi \& Poór, 2016). Sangare-Tigori, Dem, et al. (2006) reported OTA average levels higher than those found in the present study, in maize (mean $37 \mu \mathrm{g} . \mathrm{kg}^{-1}$, range 9.8-86 $\mu \mathrm{g} \cdot \mathrm{kg}^{-1}$ ), rice (mean $44 \mu \mathrm{g} \cdot \mathrm{kg}^{-1}$, range 9-92 $\mu \mathrm{g} \cdot \mathrm{kg}^{-1}$ ) and peanuts (mean 23 $\mu \mathrm{g} . \mathrm{kg}^{-1}$, range 0.6-64 $\mu \mathrm{g} . \mathrm{kg}^{-1}$ ) from Côte d'Ivoire, whereas Sangare-Tigori, Moukha, et al. (2006) quantified OTA levels ranging from 0.09 to $0.86 \mu \mathrm{g} . \mathrm{kg}^{-1}$ in maize, from 0.16 to $0.92 \mu \mathrm{g}_{\mathrm{kg}} \mathrm{kg}^{-1}$ in rice and from 0.20 to $0.64 \mu \mathrm{g} \cdot \mathrm{kg}^{-1}$ in peanuts. The frequency of OTA occurrence (30\%) in the maize flour samples analysed in the present study was higher than that (13\%) reported by Kouadio et al. (2014) in Côte d'Ivoire but the mean $\left(1.9 \mu \mathrm{g} . \mathrm{kg}^{-1}\right.$ against $\left.21 \mu \mathrm{g} \cdot \mathrm{kg}^{-1}\right)$ and range (<LOQ to $7.6 \mu \mathrm{g} \cdot \mathrm{kg}^{-}$ ${ }^{1}$ against not detected to $114 \mu \mathrm{g} \cdot \mathrm{kg}^{-1}$ ) were lower. In other African countries, OTA was found in peanut samples at lower concentrations than those quantified in the present study, but not or seldom in maize and rice samples (Abia et al., 2013; Kamala et al., 2015; Shephard et al., 2013; Toffa et al., 2013). There was the exception of rice samples from Nigeria for which more than $40 \%$ were contaminated with OTA at levels up to $1164 \mu \mathrm{g} . \mathrm{kg}^{-1}$ (Makun et al., 2011, 2007) and of maize 
samples from South Africa for which $68 \%$ contained OTA at concentrations up to $194 \mu \mathrm{g} . \mathrm{kg}^{-1}$ (Chilaka et al., 2012).

Fusarium mycotoxins are frequently detected in cereals and derived products (AFSSA, 2006). FB1 has been classified as a group 2B possible human carcinogen (IARC, 2002) and associated with oesophageal cancer and neural tube defects in humans. FB2 and FB3 toxicity is at the same level of magnitude than that of FB1 (Stockmann-Juvala \& Savolainen, 2008). Zearalenone (ZEN) has been implicated in hyper estrogenic syndromes in humans and it has also been shown to be hepatotoxic, haematotoxic, immunotoxic and genotoxic (Zinedine, Soriano, Moltó, \& Mañes, 2007). The maize samples analysed in the present study were more contaminated with FB1+FB2 than the rice samples but without exceeding the EU limit of $1000 \mu \mathrm{g} \cdot \mathrm{kg}^{-1}$ (Table 5). FB1 levels were higher than FB2 in all the cereal samples (respective means 78 and $28 \mu \mathrm{g} \cdot \mathrm{kg}^{-1}$ for maize samples; 5.3 and $2.2 \mu \mathrm{g} \cdot \mathrm{kg}^{-1}$ for rice samples). Very few maize and rice samples were contaminated with ZEN and at very low concentrations not exceeding the EU limit of $75 \mu \mathrm{g} \cdot \mathrm{kg}^{-1}$. Fumonisins (FUMs) and ZEN were not detected in the peanut paste samples (Table 5). Warth et al. (2012) and Mulunda et al. (2013) reported similar results in peanut samples that can be explained by the fact that FUMs and ZEN are produced by Fusarium spp. which primarily infect cereal grains, in particular maize (Udomkun et al., 2017). In Côte d'Ivoire, Sangare-Tigori, Moukha, et al. (2006) found FB1 levels in maize samples (range $0.3-1.5 \mu \mathrm{g} \cdot \mathrm{kg}^{-1}$ ) much lower than those analysed in the present study (range 10-587 $\mu \mathrm{g} \cdot \mathrm{kg}^{-1}$ ) and they did not detect FB1 in rice samples, whereas they quantified FB1 levels ranging from $<0.3$ to $6 \mu \mathrm{g} . \mathrm{kg}^{-1}$ in peanut samples. Contrariwise, Kouadio et al. (2014) determined higher FB1+FB2 levels (mean $356 \mu \mathrm{g} . \mathrm{kg}^{-1}$, range 93-2210 $\mu \mathrm{g} . \mathrm{kg}^{-1}$ ) in maize flour samples. Sangare-Tigori, Moukha, et al. (2006) also analysed higher ZEN concentrations in maize $\left(50 \mu \mathrm{g} \cdot \mathrm{kg}^{-1}\right)$, rice and peanut samples (range 50-200 $\mu \mathrm{g} \cdot \mathrm{kg}^{-1}$ ) as well as Kouadio et al. (2014) with ZEN determined in $57 \%$ of maize flour samples (mean $14 \mu \mathrm{g} . \mathrm{kg}^{-1}$; range not detected-109 $\mu \mathrm{g} \cdot \mathrm{kg}^{-1}$ ). In other African countries, higher ZEN contamination frequencies and levels were also found in rice (52\%, up to 42 $\left.\mu \mathrm{g} . \mathrm{kg}^{-1}\right)$ and maize (15-92\%, up to $135-811 \mu \mathrm{g} \cdot \mathrm{kg}^{-1}$ ) samples. In addition, higher FB1+FB2 contamination frequencies and levels have been reported in maize than rice samples with FB1 concentrations higher than FB2 in maize samples, but with higher FUM concentrations reaching up to $323948 \mu \mathrm{g} . \mathrm{kg}^{-1}$ for FB1 and $123814 \mu \mathrm{g} . \mathrm{kg}^{-1}$ for FB2 (Abia et al., 2013; Chilaka et al., 2012; Makun et al., 2011 ; Mulunda et al., 2013; Ogara et al., 2016; Shephard et al., 2013; Warth et al., 2012).

Among the rice samples, the local rice samples were the most contaminated with EU regulated mycotoxins. Except AFG2 that was not detected in the maize flour samples with potash, AFB1, AFG1, AFB2, OTA, FB1+FB2 and ZEN were detected in all types of maize samples. Maize flour 
samples with potash had the lowest levels of AFB1, AFT and FB1+FB2 but the highest OTA and ZEN concentrations with one sample having an OTA level exceeding the EU limit (Tables 3-5).

\subsection{Other mycotoxins}

A total of 16 additional mycotoxins were detected in the analysed food samples (Table 6). Ten were recovered from the peanut paste samples including: beauvericin (BEA), equisetin (EQUS), aflatoxin M1 (AFM1), cyclopiazonic acid (CPA) and sterigmatocystin (STER) with each in more than 70\% of the samples; ochratoxin B (OTB), enniatin B (ENN-B) and B1 (ENN-B1) at a frequency of 42\%, 25\% and 30\% respectively; diacetoxyscirpenol (DAS) and aurofusarin (AUF) with each in less than $10 \%$ of the samples. Those toxins detected in the rice samples included: EQUS and BEA in 70\% and $57 \%$ of the samples, respectively; AFM1, CPA, STER, citrinin (CIT), OTB, DAS, skyrin (SKY) and cytochalasin B (CYT-B) with each in less than $10 \%$ of the samples. Nine toxins were determined in the maize samples including: BEA, FB3, EQUS and AFM1 in 87\%, 86\%, 47\%, and $37 \%$ of the samples, respectively; fusaric acid (FA) and CIT each in $46 \%$ of the samples; OTB, CPA and agroclavine (AGC) at a frequency comprised between 5 and $14 \%$.

AFM1 was classified as a group 2B possible human carcinogen (IARC, 1993). Its acute toxicity is nearly equal to that of AFB1, but its potential carcinogenic hazard is about one order of magnitude less than that of AFB1 (Pietri \& Piva, 2007). AFM1 is excreted into the milk of dairy animals and human nursing mothers after AFB1 ingestion and bioconversion in the liver. Its occurrence in plants, produced by Aspergillus spp. through a biosynthetic pattern not involving AFB1 or possibly by insect pests' metabolism from AFB1, was also reported (Giovati et al., 2015). This could explain AFM1 presence in the cereal and peanut paste samples analysed in the present study, with the peanut paste samples being the most contaminated with this toxin. Warth et al. (2012) have also detected AFM1 in maize samples from African countries at higher concentrations, as well as Ogara et al. (2016) up to $1744 \mu \mathrm{g} \cdot \mathrm{kg}^{-1}$, but not in peanut samples.

OTB, CIT and CPA are the three non EU regulated mycotoxins produced by Aspergillus / Penicillium spp. that were found in the analysed food samples. OTB which is clearly less toxic than OTA (Heussner \& Bingle, 2015), was detected in all types of samples except maize flour samples without potash. Contamination frequency and levels were the highest in the peanut paste samples and low in the cereal samples. Abia et al. (2013) quantified lower OTB levels in peanut samples and did not detect this mycotoxin in maize samples. CIT is reported to possess nephrotoxic, cytotoxic and genotoxic effects. It is frequently found in food in combination with OTA, and suspected to be involved in the BEN (Flajs \& Peraica, 2009; Föllmann, Behm, \& Degen, 2014). CIT was found in all types of cereal samples but not in peanut paste samples. Previous studies in Africa also reported no CIT in peanut samples but levels up to $44029 \mu \mathrm{g} \cdot \mathrm{kg}^{-1}$ in maize samples (Abia et al., 2013; Ogara 
et al., 2016; Warth et al., 2012). CPA was detected in all types of samples except the local rice samples, with the highest contamination frequency and levels in peanut paste samples, and concentrations above the LOQ only in 4 maize flour samples. This mycotoxin was quantified at higher concentrations (up to $1347 \mu \mathrm{g} \cdot \mathrm{kg}^{-1}$, mean $249 \mu \mathrm{g} \cdot \mathrm{kg}^{-1}$ ) in maize samples from Nigeria (Ogara et al., 2016) and in none or only one peanut sample from Burkina Faso and Mozambique (Warth et al., 2012). Eight non EU regulated mycotoxins produced by Fusarium spp. were detected in the analysed food samples. BEA was detected in all types of samples at high frequencies of occurrence ( $>40 \%)$, with the highest found in the peanut paste samples followed by the maize and rice samples, and at concentrations not exceeding $22 \mu \mathrm{g} \cdot \mathrm{kg}^{-1}$. ENN-B and ENN-B1 were detected at low concentrations only in peanut paste samples, as well as AUF. BEA and ENNs were found to produce cytotoxic effects in several mammalian cell lines (Jestoi, 2008; Prosperini, Meca, Font, \& Ruiz, 2012). DAS was detected only in 2 local rice samples and 4 peanut paste samples at levels up to $4 \mu \mathrm{g} \mathrm{kg}^{-1}$. EQUS was found in all types of samples with the highest contamination frequency and levels in the peanut paste samples. FB3 and FA were detected only in the maize samples at levels up to 94 and $83 \mu \mathrm{g} \cdot \mathrm{kg}^{-1}$, respectively. Previous studies performed in African countries have reported higher levels of BEA, EQUS, FB3 and FA in maize samples (respectively up to $3724 \mu \mathrm{g}^{\mathrm{kg}}{ }^{-1}, 242$ $\mu \mathrm{g} \cdot \mathrm{kg}^{-1}, 63509 \mu \mathrm{g} \cdot \mathrm{kg}^{-1}$ and $\left.19466 \mu \mathrm{g} \cdot \mathrm{kg}^{-1}\right)$ but also AUF and DAS levels respectively up to 3878 $\mu \mathrm{g} . \mathrm{kg}^{-1}$ and $34 \mu \mathrm{g} \cdot \mathrm{kg}^{-1}$, and very low ENN-B and ENN-B1 concentrations not exceeding $0.4 \mu \mathrm{g} \cdot \mathrm{kg}^{-1}$ and $1 \mu \mathrm{g} . \mathrm{kg}^{-1}$, respectively (Abia et al., 2013; Ogara et al., 2016; Shephard et al., 2013). Abia el al. (2013) quantified higher levels of BEA (up to $12 \mu \mathrm{g} \cdot \mathrm{kg}^{-1}$, mean $4 \mu \mathrm{g} \cdot \mathrm{kg}^{-1}$ ) and ENN-B1 (up to 5 $\mu \mathrm{g} . \mathrm{kg}^{-1}$, mean $1.4 \mu \mathrm{g} . \mathrm{kg}^{-1}$ ) and lower ENN-B levels (up to $0.6 \mu \mathrm{g} . \mathrm{kg}^{-1}$, mean $0.1 \mu \mathrm{g} . \mathrm{kg}^{-1}$ ) in peanut samples as well as FB3 and FA levels up to $5 \mu \mathrm{g} \cdot \mathrm{kg}^{-1}$ and $189 \mu \mathrm{g} \cdot \mathrm{kg}^{-1}$, respectively. AGC was the Claviceps mycotoxin detected only in the maize samples at low concentrations. This toxin was also quantified by Shephard et al., (2013) in maize samples from South Africa at low concentrations (up to $1.8 \mu \mathrm{g} \cdot \mathrm{kg}^{-1}$ ). STER which is the most toxic AFB1 precursor, is both mutagenic and tumorigenic but less potent than AFs. It has been classified as a group 2B possible human carcinogen (Bennett \& Klich, 2003; Ezekiel, Sulyok, Warth, Odebode, \& Krska, 2012). STER was detected only in rice and peanut paste samples, with the latter being the most contaminated in frequency and levels. Contrariwise, Abia et al. (2013) and Ogara et al. (2016) found STER up to $242 \mu \mathrm{g} . \mathrm{kg}^{-1}$ in maize samples, respectively from Cameroon and Nigeria, and Warth et al. (2012) did not detect this toxin in peanut samples from Burkina Faso and in only one from Mozambique. SKY and CYT-B were detected in only one and 3 imported rice samples, respectively. SKY was found by Shephard et al. (2013) in $94 \%$ of maize samples from South Africa at levels up to $60 \mu \mathrm{g} \cdot \mathrm{kg}^{-1}$. Among the rice samples, the local rice samples were the most contaminated by the non EU regulated mycotoxins, except for OTB, STER, SKY and CYT-B. 


\section{Conclusion}

The present study is the first to provide data on such a wide range of mycotoxins in the cereal (rice grains, cracked maize and maize flour) and oilseed (peanut paste) products most consumed in Côte d'Ivoire. It revealed that these food products were highly susceptible to contamination by several EU regulated and/or other mycotoxins. Furthermore, mycotoxin concentrations exceeding EU limits were found, especially for AFB1 which is the most toxic form of AFs and the most frequently detected mycotoxin in the samples. The low concentrations found for certain mycotoxins in the analysed food samples do not exclude potential toxic risks to Ivorian consumers due to a cumulative effect depending on their dietary habits. In addition, although data on the toxic effects of non EU regulated mycotoxins as well as on the possible interactions between mycotoxins are still limited or non-existent, the occurrence of the non EU regulated mycotoxins in foods is a concern and exposure to multiple mycotoxins, especially through high-consumption food products, is expected to result in greater human health problems. Therefore, the foods analysed in this study pose a risk to the health of Ivorian consumers, with the peanut paste samples representing the highest risk in terms of number of mycotoxins detected in the same sample, frequency and levels of contamination, followed by maize then rice samples. The local rice samples were the most contaminated compared to the imported ones. This can be explained by a better quality of rice exported by Asian countries and /or by the fact that imported rice is subject to quality controls before entering the market in Côte d'Ivoire.

\section{Acknowledgments}

This work is resulting from the EU project 3CIvoire (EuropeAid/129596/L/ACT/CI DCINSAPVD/2010/64). The authors also acknowledge the EU project Collab4Safety (ID 311611) and the ASSET project, partly funded through InvestNI and the European Sustainable Competitiveness Programme for Northern Ireland 2007-2013 under the European Regional Development Fund. The views expressed are not necessarily those of the EU. This research was also supported by a grant for Ivorian $\mathrm{PhD}$ students awarded by the Service of co-operation and cultural action of the French Embassy in Côte d'Ivoire and the Ministry of Higher Education and Scientific Research of Côte d'Ivoire.

\section{References}

Abia, W. A., Warth, B., Sulyok, M., Krska, R., Tchana, A. N., Njobeh, P. B., Moundipa, P. F. (2013). Determination of multi-mycotoxin occurrence in cereals, nuts and their products in 
Cameroon by liquid chromatography tandem mass spectrometry (LC-MS/MS). Food

Control, 31(2), 438-453. https://doi.org/10.1016/j.foodcont.2012.10.006

AFSSA (Agence française de sécurité sanitaire des aliments). (2006). Risk assessment for mycotoxins in human and animal food chains. Retrieved from https://www.anses.fr/fr/system/files/RCCP-Ra-MycotoxinesEN.pdf

Alassane-Kpembi, I., Schatzmayr, G., Taranu, I., Marin, D., Puel, O., \& Oswald, I. P. (2017).

Mycotoxins co-contamination: Methodological aspects and biological relevance of combined toxicity studies. Critical Reviews in Food Science and Nutrition, 57(16), 3489-3507. https://doi.org/10.1080/10408398.2016.1140632

Bennett, J. W., \& Klich, M. (2003). Mycotoxins. Clinical Microbiology Reviews, 16(3), 497-516. https://doi.org/10.1128/CMR.16.3.497-516.2003

Boansi, D. (2013). Acreage response of rice in Côte D'ivoire: Macro-level response and some policy implications. International Journal of Agricultural Policy and Research, 1(9), 288-297.

Chala, A., Mohammed, A., Ayalew, A., \& Skinnes, H. (2013). Natural occurrence of aflatoxins in groundnut (Arachis hypogaea L.) from eastern Ethiopia. Food Control, 30(2), 602-605. https://doi.org/10.1016/j.foodcont.2012.08.023

Chilaka, C. A., De Kock, S., Phoku, J. Z., Mwanza, M., Egbuta, M. A., \& Dutton, M. F. (2012). Fungal and mycotoxin contamination of South African commercial maize. Journal of Food, Agriculture \& Environment Vol.10 (2): 296-303

EFSA (European Food Safety Authority). (2007). Opinion of the scientific panel on contaminants in the food chain on a request from the commission related to the potential increase of consumer health risk by a possible increase of the existing maximum levels for aflatoxins in almonds, hazelnuts and pistachios and derived products. Question $N^{\circ}$ EFSA-Q-2006-174. EFSA Journal, (446), 1-127.

EFSA (European Food Safety Authority) Panel on Contaminants in the Food Chain (CONTAM). (2014a). Scientific Opinion on the risks for human and animal health related to the presence of modified forms of certain mycotoxins in food and feed: Modified mycotoxins in food and feed. EFSA Journal, 12(12), 3916. https://doi.org/10.2903/j.efsa.2014.3916

EFSA (European Food Safety Authority) Panel on Contaminants in the Food Chain (CONTAM). (2014b). Scientific Opinion on the risks to human and animal health related to the presence of beauvericin and enniatins in food and feed: Beauvericin and enniatins in food and feed. EFSA Journal, 12(8), 3802. https://doi.org/10.2903/j.efsa.2014.3802

European Commission. (2006). Commission Regulation (EC) No 1881/2006 of 19 December 2006 setting maximum levels for certain contaminants in foodstuffs (Text with EEA relevance). Official Journal of European Union, (364), 5-24. 
European Commission. (2007). Commission Regulation (EC) No 1126/2007, amending Regulation (EC) No 1881/2006 setting maximum levels for certain contaminants in foodstuffs as regards Fusarium toxins in maize and maize products (Text with EEA relevance). Official Journal of European Union, (255), 14-16.

European Commission. (2010). Commission regulation (EU) No 165/2010 of 26 February 2010, amending Regulation (EC) No 1881/2006 setting maximum levels for certain contaminants in foodstuffs as regards aflatoxins (Text with EEA relevance). Official Journal of European Union, (50), 8.

European Commission. (2012). Commission regulation (EU) No 594/2012/EU of 5 July 2012 amending Regulation (EC) 1881/2006 as regards the maximum levels of the contaminants ochratoxin A, non-dioxin-like PCBs and melamine in foodstuffs (Text with EEA relevance). Official Journal of European Union, (176), 43-45.

European Commission. (2013). Recommendations (EU) No 165/2013 of 27 March 2013 on the presence of T-2 and HT-2 toxin in cereals and cereal products (Text with EEA relevance). Official Journal of European Union, (91), 12-15.

Ezekiel, C. N., Sulyok, M., Warth, B., Odebode, A. C., \& Krska, R. (2012). Natural occurrence of mycotoxins in peanut cake from Nigeria. Food Control, 27(2), 338-342. https://doi.org/10.1016/j.foodcont.2012.04.010

Flajs, D., \& Peraica, M. (2009). Toxicological Properties of Citrinin. Archives of Industrial Hygiene and Toxicology, 60(4). https://doi.org/10.2478/10004-1254-60-2009-1992

Föllmann, W., Behm, C., \& Degen, G. H. (2014). Toxicity of the mycotoxin citrinin and its metabolite dihydrocitrinone and of mixtures of citrinin and ochratoxin A in vitro. Archives of Toxicology, 88(5), 1097-1107. https://doi.org/10.1007/s00204-014-1216-8

Giovati, L., Magliani, W., Ciociola, T., Santinoli, C., Conti, S., \& Polonelli, L. (2015). AFM1 in Milk: Physical, Biological, and Prophylactic Methods to Mitigate Contamination. Toxins, 7(10), 4330-4349. https://doi.org/10.3390/toxins 7104330

Grenier, B., \& Oswald, I. (2011). Mycotoxin co-contamination of food and feed: meta-analysis of publications describing toxicological interactions. World Mycotoxin Journal, 4(3), 285-313. https://doi.org/10.3920/WMJ2011.1281

Heussner, A., \& Bingle, L. (2015). Comparative Ochratoxin Toxicity: A Review of the Available Data. Toxins, 7(10), 4253-4282. https://doi.org/10.3390/toxins7104253

IARC (International Agency for Research on Cancer). (1993). IARC monographs on the evaluation of carcinogenic risks to humans. Some naturally occurring substances: food items and constituents, heterocyclic aromatic amines and mycotoxins. Volume 56, 599 p., IARC, Lyon, France. 
IARC (International Agency for Research on Cancer). (2002). IARC monographs on the evaluation of carcinogenic risks to humans. Some traditional herbal medicines, some mycotoxins, naphthalene and styrene.Volume 82, 601 p. IARC, Lyon: France.

IARC (International Agency for Research on Cancer). (2015). Mycotoxin control in low- and middle-income countries. Retrieved from http://www.ncbi.nlm.nih.gov/books/NBK350558/

Jestoi, M. (2008). Emerging Fusarium -Mycotoxins Fusaproliferin, Beauvericin, Enniatins, And Moniliformin-A Review. Critical Reviews in Food Science and Nutrition, 48(1), 21-49. https://doi.org/10.1080/10408390601062021

Kamala, A., Ortiz, J., Kimanya, M., Haesaert, G., Donoso, S., Tiisekwa, B., \& De Meulenaer, B. (2015). Multiple mycotoxin co-occurrence in maize grown in three agro-ecological zones of Tanzania. Food Control, 54, 208-215. https://doi.org/10.1016/j.foodcont.2015.02.002

Kamika, I., \& Takoy, L. L. (2011). Natural occurrence of Aflatoxin B1 in peanut collected from Kinshasa, Democratic Republic of Congo. Food Control, 22(11), 1760-1764. https://doi.org/10.1016/j.foodcont.2011.04.010

Kőszegi, T., \& Poór, M. (2016). Ochratoxin A: Molecular Interactions, Mechanisms of Toxicity and Prevention at the Molecular Level. Toxins, 8(4), 111. https://doi.org/10.3390/toxins8040111 Kouadio, J. H., Lattanzio, V. M. T., Ouattara, D., Kouakou, B., \& Visconti, A. (2014). Assessment of mycotoxin exposure in Côte D'Ivoire (Ivory Coast) through multi-biomarker analysis and possible correlation with food consumption patterns. Toxicol Int, 21(3), 248-257. https://doi.org/10.4103/0971-6580.155336

Makun, H. A., Gbodi, T. A., Akanya, O. H., Salako, E. A., \& Ogbadu, G. H. (2007). Fungi and some mycotoxins contaminating rice (Oryza sativa) in Niger state, Nigeria. African Journal of Biotechnology, 6(2). Retrieved from https://www.ajol.info/index.php/ajb/article/view/56106

Makun, H. A., Dutton, M. F., Njobeh, P. B., Mwanza, M., \& Kabiru, A. Y. (2011). Natural multioccurrence of mycotoxins in rice from Niger State, Nigeria. Mycotoxin Research, 27(2), 97 - 104. https://doi.org/10.1007/s12550-010-0080-5

Mulunda, M., Dzoma, B., Nyirenda, M., \& Bakunzi, F. (2013). Mycotoxins occurrence in selected staple food in main markets from Lubumbashi, Democratic Republic of Congo. Journal of Food, Agriculture \& Environment, 11(3\&4), 51-54.

Mutegi, C. K., Ngugi, H. K., Hendriks, S. L., \& Jones, R. B. (2009). Prevalence and factors associated with aflatoxin contamination of peanuts from Western Kenya. International Journal of Food Microbiology, 130(1), 27-34.

https://doi.org/10.1016/j.ijfoodmicro.2008.12.030 
Ogara, I. M., Zarafi, A. B., Alabi, O., Banwo, O., Ezekiel, C. N., Warth, B., Krska, R. (2016). Mycotoxin patterns in ear rot infected maize: A comprehensive case study in Nigeria. Food Control, 73, 1159-1168. https://doi.org/10.1016/j.foodcont.2016.10.034

Oplatowska-Stachowiak, M., Haughey, S. A., Chevallier, O. P., Galvin-King, P., Campbell, K., Magowan, E., Elliott, C. T. (2015). Determination of the Mycotoxin Content in Distiller's Dried Grain with Solubles Using a Multianalyte UHPLC-MS/MS Method. Journal of Agricultural and Food Chemistry, 63(43), 9441-9451.

https://doi.org/10.1021/acs.jafc.5b03844

Pietri, A., \& Piva, G. (2007). Aflatoxins in foods. Italian Journal of Public Health, 4(1). Retrieved from http://ijphjournal.it/article/view/5899

Prosperini, A., Meca, G., Font, G., \& Ruiz, M. J. (2012). Study of the cytotoxic activity of beauvericin and fusaproliferin and bioavailability in vitro on Caco-2 cells. Food and Chemical Toxicology, 50(7), 2356-2361. https://doi.org/10.1016/j.fct.2012.04.030

Rychlik, M., Humpf, H.-U., Marko, D., Dänicke, S., Mally, A., Berthiller, F., Lorenz, N. (2014). Proposal of a comprehensive definition of modified and other forms of mycotoxins including 'masked' mycotoxins. Mycotoxin Research, 30(4), 197-205. https://doi.org/10.1007/s12550014-0203-5

Sangare, A., Koffi, E., Akamou, F., \& Fall, C. A. (2009). Rapport national sur l'état des ressources phytogénétiques pour l'alimentation et l'agriculture. Ministère de l'agriculture, République de Côte d'Ivoire. 65p.

Sangare-Tigori, Dem, A., Kouadio, H., Betbeder, A.-M., Dano, D., Moukha, S., \& Creppy, E. (2006). Preliminary survey of ochratoxin A in millet, maize, rice and peanuts in Côte d'Ivoire from 1998 to 2002. Human \& Experimental Toxicology, 25(4), 211-216. https://doi.org/10.1191/0960327106ht605oa

Sangare-Tigori, Moukha, S., Kouadio, H. J., Betbeder, A.-M., Dano, D. S., \& Creppy, E. E. (2006). Co-occurrence of aflatoxin $\mathrm{B}_{1}$, fumonisin $\mathrm{B}_{1}$, ochratoxin A and zearalenone in cereals and peanuts from Côte d'Ivoire. Food Additives and Contaminants, 23(10), 1000-1007. https://doi.org/10.1080/02652030500415686

Shephard, G. S., Burger, H.-M., Gambacorta, L., Krska, R., Powers, S. P., Rheeder, J. P., ... van der Westhuizen, L. (2013). Mycological Analysis and Multimycotoxins in Maize from Rural Subsistence Farmers in the Former Transkei, South Africa. Journal of Agricultural and Food Chemistry, 61(34), 8232-8240. https://doi.org/10.1021/jf4021762

Stockmann-Juvala, H., \& Savolainen, K. (2008). A review of the toxic effects and mechanisms of action of fumonisin B1. Human \& Experimental Toxicology, 27(11), 799-809. https://doi.org/10.1177/0960327108099525 
Toffa, D. D., Mahnine, N., Ouaffak, L., Abidi, A. El, Alaoui Faris, F. Z. El, \& Zinedine, A. (2013). First survey on the presence of ochratoxin A and fungi in raw cereals and peanut available in the Republic of Niger. Food Control, 32(2), 558-562. https://doi.org/10.1016/i.foodcont.2013.01.028

Udomkun, P., Wiredu, A. N., Nagle, M., Bandyopadhyay, R., Müller, J., \& Vanlauwe, B. (2017). Mycotoxins in Sub-Saharan Africa: Present situation, socio-economic impact, awareness, and outlook. Food Control, 72, 110-122. https://doi.org/10.1016/j.foodcont.2016.07.039

USDA (United States Departement of Agriculture), Foreign Agricultural Service. 2015 Update West Africa Rice Annual. Grain and Feed Annual. Gain report, Global Agricultural Information Network, Senegal, 04/29/2015, 18 p.

Van Egmond, H. P., Schothorst, R. C., \& Jonker, M. A. (2007). Regulations relating to mycotoxins in food: Perspectives in a global and European context. Analytical and Bioanalytical Chemistry, 389(1), 147-157. https://doi.org/10.1007/s00216-007-1317-9

Warth, B., Parich, A., Atehnkeng, J., Bandyopadhyay, R., Schuhmacher, R., Sulyok, M., \& Krska, R. (2012). Quantitation of Mycotoxins in Food and Feed from Burkina Faso and Mozambique Using a Modern LC-MS/MS Multitoxin Method. Journal of Agricultural and Food Chemistry, 60(36), 9352-9363. https://doi.org/10.1021/jf302003n

Yeo, Y. A. (2011). Analyse de la compétitivité du maïs local en Côte d'Ivoire. PRESAO (Programme de Renforcement et de Recherche sur la Sécurité Alimentaire en Afrique de l'Ouest). Composante SRAI (Strengthening Regional Agricultural Integration in West Africa), Résumé N², 2011-12, Maïs, Décembre 2011, 10 p. Retrieved from http://fsg.afre.msu.edu/srai/index.htm

Zain, M. E. (2011). Impact of mycotoxins on humans and animals. Journal of Saudi Chemical Society, 15(2), 129-144. https://doi.org/10.1016/j.jscs.2010.06.006

Zinedine, A., Soriano, J. M., Moltó, J. C., \& Mañes, J. (2007). Review on the toxicity, occurrence, metabolism, detoxification, regulations and intake of zearalenone: An oestrogenic mycotoxin. Food and Chemical Toxicology, 45(1), 1-18. https://doi.org/10.1016/j.fct.2006.07.030 
Table 1: Limits of detection and quantification of the UHPLC-MS/MS method used for the analysis of 77 mycotoxins in rice, maize and peanut samples collected in Côte d'Ivoire

\begin{tabular}{|c|c|c|c|}
\hline Mycotoxins / Abbreviation & Toxin Source & $\begin{array}{l}\text { Limit of detection } \\
\text { (LOD) in solvent } \\
{\left[\mu \mathrm{g} \cdot \mathrm{kg}^{-1}\right]}\end{array}$ & $\begin{array}{l}\text { Limit of } \\
\text { quantification (LOQ) } \\
\text { in solvent } \\
{\left[\mu \mathrm{g} \cdot \mathrm{kg}^{-1}\right]}\end{array}$ \\
\hline \multicolumn{4}{|c|}{ EU regulated mycotoxins in foodstuffs } \\
\hline \multicolumn{4}{|l|}{ Aspergillus mycotoxins } \\
\hline Aflatoxin B1 / AFB1 & Romer Labs & 0.05 & 0.25 \\
\hline Aflatoxin B2 / AFB2 & \multirow{4}{*}{ Sigma } & 0.12 & 0.25 \\
\hline Aflatoxin G1 / AFG1 & & 0.12 & 0.25 \\
\hline Aflatoxin G2 / AFG2 & & 0.12 & 0.25 \\
\hline Aflatoxin M1 / AFM1 & & 0.05 & 0.25 \\
\hline \multicolumn{4}{|l|}{ Fusarium mycotoxins } \\
\hline Deoxynivalenol / DON & Romer Labs & 5 & 12.5 \\
\hline Fumonisin B1 / FB1 & Sigma & 0.5 & 1 \\
\hline Fumonisin B2 / FB2 & Sigma & 0.5 & 1 \\
\hline Zearalenone / ZEN & Romer Labs & 2.5 & 5 \\
\hline \multicolumn{4}{|l|}{ Aspergillus / Penicillium mycotoxins } \\
\hline Citrinin / CIT & Tebu-Bio & 10 & 25 \\
\hline Ochratoxin A / OTA & Romer Labs & 0.25 & 0.62 \\
\hline Patulin & Fisher & 50 & 125 \\
\hline \multicolumn{4}{|c|}{ Fusarium mycotoxins with EU recommended limits in cereal and cereal products } \\
\hline T-2 toxin & Romer Labs & 2.5 & 5 \\
\hline HT-2 toxin & EnzoLife Sciences & 25 & 50 \\
\hline \multicolumn{4}{|c|}{ Metabolites of EU regulated Fusarium mycotoxins } \\
\hline 3-acetyldeoxynivalenol / 3-AcDON & Romer Labs & 12.5 & 25 \\
\hline $15-\mathrm{AcDON}$ & Romer Labs & 25 & 50 \\
\hline Deepoxy-DON & Sigma & 2.5 & 5 \\
\hline Zearalanone & \multirow{5}{*}{ Tebu-Bio } & 5 & 10 \\
\hline$\alpha$-zearalanol / $\alpha$-ZAL & & 125 & 250 \\
\hline$\beta-Z A L$ & & 125 & 250 \\
\hline$\alpha$-zearalenol / $\alpha$-ZEL & & 50 & 125 \\
\hline$\beta-Z E L$ & & 50 & 125 \\
\hline \multicolumn{4}{|l|}{ Emerging Fusarium mycotoxins } \\
\hline Beauvericin / BEA & Romer Labs & 0.005 & 0.01 \\
\hline Enniatin A & \multirow{5}{*}{ Tebu-Bio } & 0.02 & 0.05 \\
\hline Enniatin A1 & & 0.02 & 0.05 \\
\hline Enniatin B / ENN-B & & 0.02 & 0.05 \\
\hline Enniatin B1 / ENN-B1 & & 0.02 & 0.05 \\
\hline Moniliformin / MON & & 62.5 & 125 \\
\hline \multicolumn{4}{|c|}{ Fusarium mycotoxins conjugated by plants (masked mycotoxins) or fungi* } \\
\hline DON-3-glucoside / DON-3-Glc & Romer Labs & 125 & 250 \\
\hline ZEN-14-Glc & \multirow{5}{*}{$\begin{array}{l}\text { Department of } \\
\text { Agrobiotechnology, } \\
\text { IFA-Tulln }\end{array}$} & 5 & 12.5 \\
\hline$\alpha$-ZEL-14-Glc & & 25 & 50 \\
\hline$\beta-Z E L-14-G l c$ & & 12.5 & 25 \\
\hline ZEN-16-Glc & & 1 & 2.5 \\
\hline ZEN-14-sulfate* & & 1 & 2.5 \\
\hline \multicolumn{4}{|l|}{ Other Fusarium mycotoxins } \\
\hline Apicidin & EnzoLife Sciences & 5 & 10 \\
\hline Aurofusarin / AUF & Insight Biotechnology & 0.62 & 1.25 \\
\hline Diacetoxyscirpenol / DAS & Discovery Fine Chemicals & 1.25 & 2.5 \\
\hline Equisetin / EQUS & Insight Biotechnology & 0.25 & 0.62 \\
\hline Fumonisin B3 / FB3 & \multirow{2}{*}{ Romer Labs } & 0.5 & 1 \\
\hline Fusarenon X & & 12.5 & 25 \\
\hline Fusaric acid / FA & Fisher Scientific & 2.5 & 5 \\
\hline Neosolaniol & \multirow{2}{*}{ Romer Labs } & 1 & 2.5 \\
\hline Nivalenol & & 62.5 & 125 \\
\hline Verrucarol & Sigma & 25 & 50 \\
\hline
\end{tabular}




\begin{tabular}{|c|c|c|c|}
\hline Penicillium mycotoxins & & & \\
\hline Curvularin & Insight Biotechnology & 2.5 & 5 \\
\hline Meleagrin & \multirow{2}{*}{ Tebu-Bio } & 0.06 & 0.12 \\
\hline Mycophenolic acid & & 0.62 & 1.25 \\
\hline Penicillic acid & Cambridge Biosciences & 5 & 10 \\
\hline Roquefortine $\mathrm{C}$ & Romer Labs & 0.05 & 0.12 \\
\hline \multicolumn{4}{|c|}{ Aspergillus / Penicillium mycotoxins } \\
\hline Cyclopiazonic acid / CPA & Abcam & 2.5 & 6.25 \\
\hline Ochratoxin B / OTB & Insight Biotechnology & 0.25 & 0.62 \\
\hline Verruculogen & Romer Labs & 0.62 & 1.25 \\
\hline \multicolumn{4}{|l|}{ Alternaria mycotoxins } \\
\hline Altenuene & Analyticon Discovery & 2.5 & 5 \\
\hline Alternariol & \multirow{2}{*}{ Insight Biotechnology } & 2.5 & 5 \\
\hline Alternariolmonomethylether & & 5 & 10 \\
\hline Macrosporin & \multirow{2}{*}{ EnzoLife Sciences } & 25 & 50 \\
\hline Tentoxin & & 1.25 & 2.5 \\
\hline \multicolumn{4}{|c|}{ Claviceps mycotoxins (ergot alkaloids) } \\
\hline Agroclavine / AGC & \multirow{13}{*}{ Romer Labs } & 0.25 & 0.62 \\
\hline Ergocornine & & 0.62 & 1.25 \\
\hline Ergocorninine & & 0.02 & 0.06 \\
\hline Ergocristine & & 0.62 & 1.25 \\
\hline Ergocristinine & & 0.02 & 0.06 \\
\hline Ergocryptine & & 0.25 & 0.62 \\
\hline Ergocryptinine & & 0.02 & 0.06 \\
\hline Ergometrine & & 0.12 & 0.25 \\
\hline Ergometrinine & & 0.06 & 0.12 \\
\hline Ergosine & & 0.25 & 0.62 \\
\hline Ergosinine & & 0.06 & 0.12 \\
\hline Ergotamine & & 0.12 & 0.25 \\
\hline Ergotaminine & & 0.06 & 0.12 \\
\hline \multicolumn{4}{|l|}{ Other fungal mycotoxins } \\
\hline Cytochalasin B / CYT-B & Tebu-Bio & 1.25 & 2.5 \\
\hline Emodin & Cambridge Biosciences & 25 & 50 \\
\hline Gliotoxin & \multirow{2}{*}{ Tebu-Bio } & 2.5 & 5 \\
\hline Penitrem A & & 0.5 & 1 \\
\hline Skyrin / SKY & EnzoLife Sciences & 10 & 25 \\
\hline Stachybotrylactam & Insight Biotechnology & 0.25 & 0.62 \\
\hline Sterigmatocystin / STER & EnzoLife Sciences & 0.62 & 1.25 \\
\hline
\end{tabular}


Table 2: Number of mycotoxins found in the same sample for the different types of food samples collected in Côte d'Ivoire

\begin{tabular}{|c|c|c|c|c|c|c|c|}
\hline \multirow[b]{2}{*}{ Food sample (n) } & \multirow[b]{2}{*}{$\begin{array}{l}\text { Minimum number } \\
\text { of mycotoxins }>1\end{array}$} & \multirow[b]{2}{*}{$\begin{array}{l}\text { Maximum number } \\
\text { of mycotoxins }\end{array}$} & \multicolumn{5}{|c|}{$\begin{array}{l}\% \text { (number) of samples according to number of } \\
\text { mycotoxins detected in the same sample }\end{array}$} \\
\hline & & & 0 & 1 & $2-4$ & $5-7$ & $\geq 8$ \\
\hline Rice samples (88) & 2 & 8 & $14(12)$ & $10(9)$ & $49(43)$ & $25(22)$ & $2(2)$ \\
\hline Imported rice (41) & 2 & 6 & $29(12)$ & $20(8)$ & $39(16)$ & $12(5)$ & - \\
\hline Local rice (47) & 2 & 8 & - & $2(1)$ & $58(27)$ & $36(17)$ & $4(2)$ \\
\hline Maize sample (79) & 2 & 14 & - & - & $10(8)$ & $32(25)$ & $58(46)$ \\
\hline Cracked maize (29) & 2 & 12 & - & - & $10(3)$ & $38(11)$ & $52(15)$ \\
\hline Maize flour with potash (32) & 2 & 14 & - & - & $16(5)$ & $34(11)$ & $50(16)$ \\
\hline Maize flour without potash (18) & 6 & 14 & - & - & - & $17(3)$ & $83(15)$ \\
\hline Peanut paste samples (71) & 5 & 13 & - & - & - & $6(4)$ & $94(67)$ \\
\hline
\end{tabular}

$\mathrm{n}=$ total number of collected samples 
Table 3: Occurrence of aflatoxins B1 (AFB1) and G1 (AFG1), and total aflatoxins (AFT=AFB1+AFB2+AFG1+AFG2) in food samples collected in Côte d'Ivoire

\begin{tabular}{|c|c|c|c|c|c|c|c|c|c|c|}
\hline \multirow[b]{2}{*}{ Mycotoxins } & \multirow[b]{2}{*}{ Food sample (n) } & \multirow[b]{2}{*}{$\begin{array}{l}\text { Frequency \% } \\
\left(\mathrm{n}^{\prime}\right)\end{array}$} & \multirow[b]{2}{*}{$\begin{array}{l}\text { Mean (Range) } \\
\mu \mathrm{g} . \mathrm{kg}^{-1}\end{array}$} & \multicolumn{7}{|c|}{$\begin{array}{l}\text { Number of contaminated samples according to mycotoxin levels (X) } \\
\mu \mathrm{g} \mathrm{kg}^{-1}\end{array}$} \\
\hline & & & & $\mathrm{X}<2$ & $2 * \leq X<4$ & $4 * * \leq X<20$ & $20 \leq X<50$ & $50 \leq X<100$ & $100 \leq X<500$ & $X \geq 500$ \\
\hline \multirow[t]{6}{*}{ AFB1 } & Imported rice (41) & $46(19)$ & $1.0(<\mathrm{LOQ}-2.9)$ & 18 & 1 & - & - & - & - & - \\
\hline & Local rice $(47)$ & $66(31)$ & $3.9(<\mathrm{LOQ}-14)$ & 11 & 8 & 12 & - & - & - & - \\
\hline & Cracked maize (29) & $97(28)$ & $8.2(0.3-80)$ & 10 & 5 & 11 & 1 & 1 & - & - \\
\hline & Maize flour with potash (32) & $94(30)$ & $7.2(<\mathrm{LOQ}-49)$ & 15 & 5 & 6 & 4 & - & - & - \\
\hline & Maize flour without potash (18) & $100(18)$ & $12(0.3-57)$ & 5 & 3 & 8 & 1 & 1 & - & - \\
\hline & Peanut paste $(71)$ & $100(71)$ & $260(0.6-4535)$ & 1 & 1 & 6 & 12 & 12 & 32 & 7 \\
\hline \multirow[t]{6}{*}{ AFG1 } & Imported rice $(41)$ & $7(3)$ & $0.4(0.3-0.7)$ & 3 & - & - & - & - & - & - \\
\hline & Local rice $(47)$ & $34(16)$ & $3.3(<\mathrm{LOQ}-17)$ & 10 & 3 & 3 & - & - & - & - \\
\hline & Cracked maize (29) & $66(19)$ & $7.3(0.3-84)$ & 13 & 1 & 3 & 1 & 1 & - & - \\
\hline & Maize flour with potash (32) & $38(12)$ & $1.9(0.4-7.5)$ & 8 & 3 & 1 & - & - & - & - \\
\hline & Maize flour without potash (18) & $89(16)$ & $5.6(0.5-11)$ & 5 & 2 & 9 & - & - & - & - \\
\hline & Peanut paste (71) & $100(71)$ & $143(0.7-2194)$ & 3 & - & 17 & 15 & 11 & 21 & 4 \\
\hline \multirow[t]{6}{*}{ AFT } & Imported rice $(41)$ & $46(19)$ & $1.1(<\mathrm{LOQ}-4.1)$ & 18 & - & 1 & - & - & - & - \\
\hline & Local rice $(47)$ & $66(31)$ & $5.8(<\mathrm{LOQ}-33)$ & 9 & 8 & 13 & 2 & - & - & - \\
\hline & Cracked maize (29) & $97(28)$ & $14(0.3-173)$ & 9 & 3 & 12 & 3 & - & 1 & - \\
\hline & Maize flour with potash (32) & $94(30)$ & $8.7(<\mathrm{LOQ}-56)$ & 14 & 5 & 7 & 3 & 1 & - & - \\
\hline & Maize flour without potash (18) & $100(18)$ & $18(0.8-67)$ & 2 & 3 & 4 & 8 & 1 & - & - \\
\hline & Peanut paste $(71)$ & $100(71)$ & $530(1.4-8094)$ & 1 & - & 4 & 3 & 12 & 35 & 16 \\
\hline
\end{tabular}

$\mathrm{n}=$ total number of collected samples; $\mathrm{n}{ }^{\prime}=$ number of contaminated samples; ${ }^{*},{ }^{* *}$ EU limits respectively for AFB1 and AFT in cereals, peanuts and derived products intended for direct human consumption; $\angle \mathrm{LOQ}=$ less than the limit of quantification 
Table 4: Ochratoxin A (OTA) occurrence in food samples collected in Côte d'Ivoire

\begin{tabular}{|c|c|c|c|c|c|c|c|}
\hline \multirow[b]{2}{*}{ Food sample (n) } & \multirow[b]{2}{*}{ Frequency \% (n’) } & \multirow[b]{2}{*}{$\begin{array}{l}\text { Mean (Range) } \\
\mu \mathrm{g} \cdot \mathrm{kg}^{-1}\end{array}$} & \multicolumn{5}{|c|}{$\begin{array}{l}\text { Number of contaminated samples } \\
\text { according to mycotoxin levels }(X) \mu \mathrm{g} \mathrm{kg}{ }^{-1}\end{array}$} \\
\hline & & & $\mathrm{X}<3^{*}$ & $3 \leq X<15$ & $15 \leq X<30$ & $30 \leq \mathrm{X}<60$ & $X \geq 60$ \\
\hline Imported rice $(41)$ & $12(5)$ & $2.7(<\mathrm{LOQ}-7.9)$ & 4 & 1 & - & - & - \\
\hline Local rice (47) & $17(8)$ & $6.3(<\mathrm{LOQ}-15)$ & 6 & 1 & 1 & - & - \\
\hline Cracked maize (29) & $7(2)$ & $1.8(1.8)$ & 2 & - & - & - & - \\
\hline Maize flour with potash (32) & $16(5)$ & $3.4(<\mathrm{LOQ}-7.6)$ & 4 & 1 & - & - & - \\
\hline Maize flour without potash (18) & $56(10)$ & $1.3(0.7-1.9)$ & 10 & - & - & - & - \\
\hline Peanut paste (71) & $65(46)$ & $9.8(<\mathrm{LOQ}-147)$ & 24 & 17 & 2 & 2 & 1 \\
\hline
\end{tabular}

$\mathrm{n}=$ total number of collected samples; $\mathrm{n}$ ' = number of contaminated samples; * EU limit for OTA in cereals and cereal products intended for direct human consumption, no EU limit for peanut products; $\angle \mathrm{LOQ}=$ less than the limit of quantification

Table 5: Occurrence of fumonisins B1 and B2 (FB1+FB2) and zearalenone (ZEN) in food samples collected in Côte d'Ivoire

\begin{tabular}{llll}
\hline Mycotoxins & Food sample (n) & Frequency \% (n') & $\begin{array}{l}\text { Mean (Range) } \\
\boldsymbol{\mu g . k g}^{-1}\end{array}$ \\
\hline FB1+FB2 & Imported rice (41) & $2(1)$ & 2.6 \\
& Local rice (47) & $32(15)$ & $6.0(2.7-13)$ \\
& Cracked maize (29) & $97(28)$ & $99(11-706)$ \\
& Maize flour with potash (32) & $81(26)$ & $73(14-214)$ \\
& Maize flour without potash (18) & $100(18)$ & $162(2.3-319)$ \\
& Peanut paste (71) & nd & nd \\
\hline ZEN & Imported rice (41) & $9(4)$ & nd \\
& Local rice (47) & $3(1)$ & $6.6(<$ LOQ -7.5) \\
& Cracked maize (29) & $13(4)$ & $6.6(<$ LOQ -7.7) \\
& Maize flour with potash (32) & $<$ LOQ \\
& Maize flour without potash (18) & $6(1)$ & nd \\
\hline
\end{tabular}

$\mathrm{n}=$ total number of collected samples; $\mathrm{n}^{\prime}=$ number of contaminated samples; $\mathrm{nd}=$ not detected, i.e. less than the limit of detection; $<\mathrm{LOQ}=$ less than the limit of quantification 
Table 6: Occurrence of other mycotoxins, non EU regulated in cereals (maize and rice), peanuts and derived products intended for direct human consumption, in food samples collected in Côte d'Ivoire

\begin{tabular}{|c|c|c|c|c|c|c|c|c|c|c|c|c|}
\hline \multirow[t]{3}{*}{ Mycotoxins } & \multicolumn{12}{|c|}{ Food sample } \\
\hline & \multicolumn{2}{|c|}{$\begin{array}{l}\text { Imported rice } \\
(\mathrm{n}=41)\end{array}$} & \multicolumn{2}{|l|}{$\begin{array}{l}\text { Local rice } \\
(\mathrm{n}=47)\end{array}$} & \multicolumn{2}{|c|}{$\begin{array}{l}\text { Cracked maize } \\
(\mathrm{n}=29)\end{array}$} & \multicolumn{2}{|c|}{$\begin{array}{l}\text { Maize flour with potash } \\
(\mathrm{n}=32)\end{array}$} & \multicolumn{2}{|c|}{$\begin{array}{l}\text { Maize flour without potash } \\
(\mathrm{n}=18)\end{array}$} & \multicolumn{2}{|c|}{$\begin{array}{l}\text { Peanut paste } \\
(\mathrm{n}=71)\end{array}$} \\
\hline & F \% (n') & $\begin{array}{l}\begin{array}{l}\text { Mean } \\
\text { (range) }\end{array} \\
\mu \mathrm{g} . \mathrm{kg}^{-1}\end{array}$ & F \% (n') & $\begin{array}{l}\begin{array}{l}\text { Mean } \\
\text { (range) } \\
\mu g^{-k g}{ }^{-1}\end{array}\end{array}$ & F \% (n') & $\begin{array}{l}\begin{array}{l}\text { Mean } \\
\text { (range) } \\
\mu \mathrm{g} . \mathrm{kg}^{-1}\end{array}\end{array}$ & F \% (n') & $\begin{array}{l}\text { Mean } \\
\text { (range) } \\
\mu \text { g.kg }^{-1}\end{array}$ & F \% (n') & $\begin{array}{l}\begin{array}{l}\text { Mean } \\
\text { (range) } \\
\mu \text { g.kg }^{-1}\end{array}\end{array}$ & F \% (n') & $\begin{array}{l}\begin{array}{l}\text { Mean } \\
\text { (range) } \\
\mu \mathrm{g} . \mathrm{kg}^{-1}\end{array}\end{array}$ \\
\hline Aflatoxin M1 & $2(1)$ & 0.4 & $13(6)$ & $\begin{array}{l}0.5 \\
(<\mathrm{LOQ}-0.8)\end{array}$ & $38(11)$ & $\begin{array}{l}1.1 \\
(0.4-5.3)\end{array}$ & $25(8)$ & $\begin{array}{l}0.9 \\
(0.4-1.7)\end{array}$ & $56(10)$ & $\begin{array}{l}0.9 \\
(0.4-2.8)\end{array}$ & $99(70)$ & 20 \\
\hline Agroclavine & nd & nd & nd & nd & $24(7)$ & $\begin{array}{l}1.0 \\
(<\mathrm{LOQ}-1.4)\end{array}$ & $3(1)$ & 0.7 & $11(2)$ & $\begin{array}{l}2.9 \\
(2.4-3.5)\end{array}$ & $\mathrm{nd}$ & nd \\
\hline Aurofusarin & nd & nd & nd & nd & nd & nd & nd & nd & nd & nd & $7(5)$ & $\begin{array}{l}3.2 \\
(2.6-4.2)\end{array}$ \\
\hline Beauvericin & $41(17)$ & $\begin{array}{l}0.3 \\
(0.1-0.6)\end{array}$ & $70(33)$ & $\begin{array}{l}1.2 \\
(0.1-12)\end{array}$ & $97(28)$ & $\begin{array}{l}2.7 \\
(0.3-22)\end{array}$ & $94(30)$ & $\begin{array}{l}1.9 \\
(0.4-5.0)\end{array}$ & $61(11)$ & $\begin{array}{l}1.6 \\
(0.5-4.6)\end{array}$ & $99(70)$ & $\begin{array}{l}1.5 \\
(0.1-11)\end{array}$ \\
\hline Citrinin & $2(1)$ & 29 & $13(6)$ & $\begin{array}{l}56 \\
(<\text { LOO-101) }\end{array}$ & $52(15)$ & $\begin{array}{l}57 \\
(<\text { LOO-146) }\end{array}$ & $56(18)$ & $\begin{array}{l}386 \\
(<\mathrm{LOO}-2394)\end{array}$ & $17(3)$ & $\begin{array}{l}84 \\
(52-122)\end{array}$ & nd & nd \\
\hline Cyclopiazonic acid & $2(1)$ & $<\mathrm{LOQ}$ & nd & nd & $7(2)$ & $<\mathrm{LOQ}$ & $19(6)$ & 13 & $17(3)$ & 10 & $90(64)$ & $\begin{array}{l}31 \\
(<\mathrm{LOQ}-132)\end{array}$ \\
\hline Cytochalasin B & $7(3)$ & $\begin{array}{l}4.3 \\
(<\text { LOQ-5.0) }\end{array}$ & nd & nd & nd & nd & nd & nd & nd & nd & nd & nd \\
\hline Diacetoxyscirpenol & nd & nd & $4(2)$ & $\begin{array}{l}2.9 \\
(<\mathrm{LOQ}-2.9)\end{array}$ & nd & nd & nd & nd & nd & nd & $6(4)$ & $\begin{array}{l}4.0 \\
(<\mathrm{LOQ}-4.0)\end{array}$ \\
\hline Enniatin B & nd & nd & nd & nd & nd & nd & nd & nd & nd & nd & $25(18)$ & $\begin{array}{l}0.9 \\
(0.4-2.6)\end{array}$ \\
\hline Enniatin B1 & nd & nd & nd & nd & nd & nd & nd & nd & nd & nd & $30(21)$ & $\begin{array}{l}0.7 \\
(0.3-2.4)\end{array}$ \\
\hline Equisetin & $41(17)$ & $\begin{array}{l}1.7 \\
(<\text { LOQ-6.2) }\end{array}$ & $96(45)$ & $\begin{array}{l}10 \\
(0.6-115)\end{array}$ & $38(11)$ & $\begin{array}{l}1.8 \\
(0.7-4.1)\end{array}$ & 59 (19) & $\begin{array}{l}1.9 \\
(<\text { LOQ-4.7) }\end{array}$ & 39 (7) & $\begin{array}{l}2.2 \\
(<\mathrm{LOQ}-3.8)\end{array}$ & $99(70)$ & $\begin{array}{l}15 \\
(<\mathrm{LOQ}-140)\end{array}$ \\
\hline Fumonisin B3 & nd & nd & nd & nd & $86(25)$ & $\begin{array}{l}17 \\
(2.2-83)\end{array}$ & $78(25)$ & $\begin{array}{l}14 \\
(3.1-35)\end{array}$ & $100(18)$ & $\begin{array}{l}25 \\
(2.1-55)\end{array}$ & nd & nd \\
\hline Fusaric acid & nd & nd & nd & nd & $24(7)$ & 23 & $53(17)$ & $\begin{array}{l}30 \\
(7.0-94)\end{array}$ & $67(12)$ & $\begin{array}{l}22 \\
(8.5-29)\end{array}$ & nd & nd \\
\hline Ochratoxin B & $5(2)$ & $\begin{array}{l}1.5 \\
(<\text { LOQ-1.5) }\end{array}$ & $4(2)$ & $\begin{array}{l}0.9 \\
(0.7-1.1)\end{array}$ & $7(2)$ & $<\mathrm{LOQ}$ & $6(2)$ & $\begin{array}{l}1.1 \\
(<\mathrm{LOQ}-1.1)\end{array}$ & nd & nd & $42(30)$ & $\begin{array}{l}19 \\
(0.7-260)\end{array}$ \\
\hline Skyrin & $2(1)$ & 50 & nd & nd & nd & nd & nd & nd & nd & nd & nd & nd \\
\hline Sterigmatocystin & 7 (3) & $\begin{array}{l}4.7 \\
(<\text { LOQ-7.8) }\end{array}$ & $9(4)$ & $\begin{array}{l}2.6 \\
(<\text { LOQ-4.8) }\end{array}$ & nd & $\mathrm{Nd}$ & nd & nd & nd & nd & $70(50)$ & $\begin{array}{l}8.1 \\
(<\mathrm{LOQ}-40)\end{array}$ \\
\hline
\end{tabular}

$\mathrm{n}=$ total number of collected samples; $\mathrm{n}$ ' = number of contaminated samples; $\mathrm{F}=$ frequency; $\mathrm{nd}=$ not detected, i.e. less than the limit of detection; $\angle \mathrm{LOQ}=$ less than the limit of quantification 


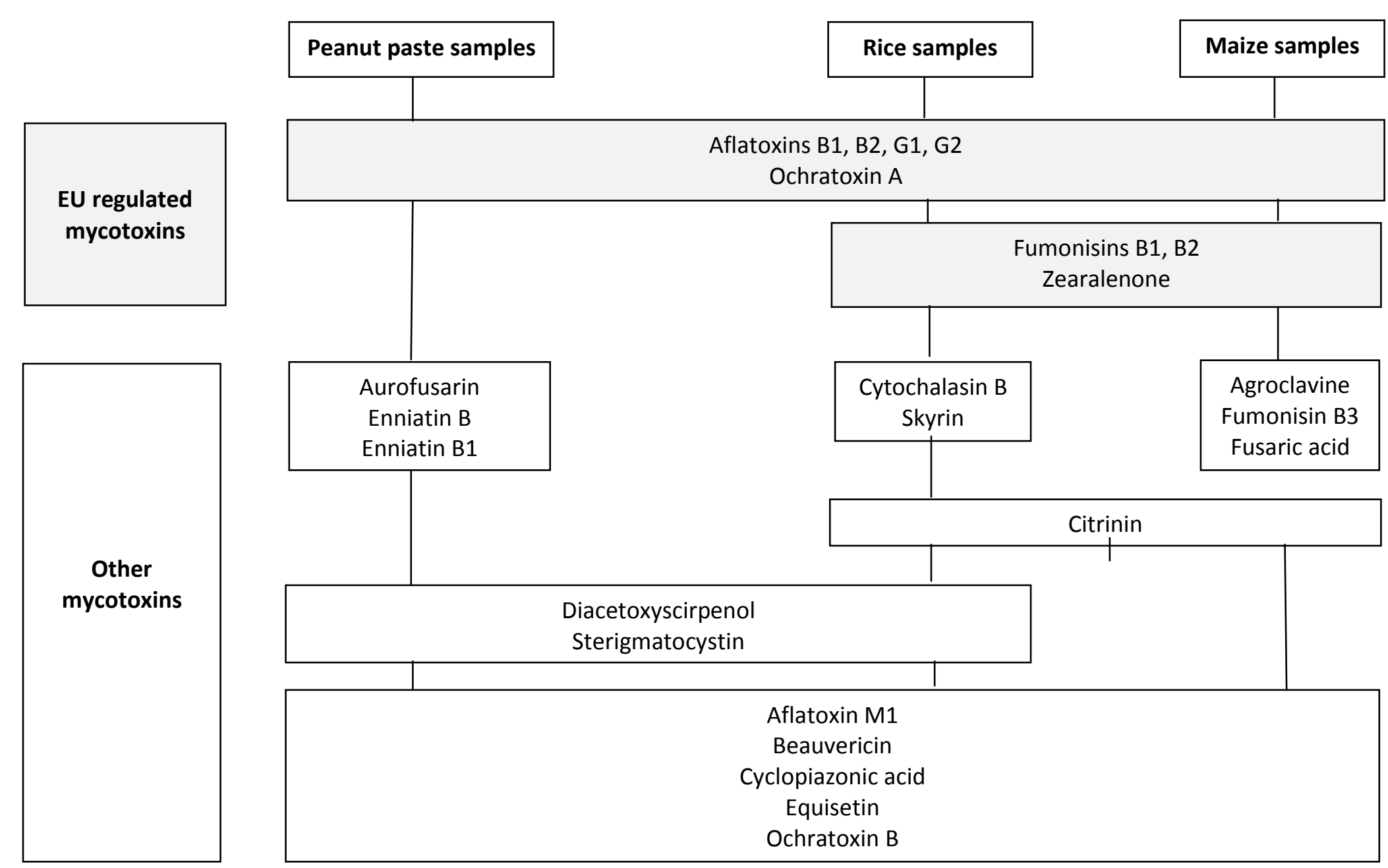

Figure 1: Multi-mycotoxin occurrence in food samples collected in Côte d'Ivoire 